\title{
PENINGKATAN KEUNGGULAN BERSAING MELALUI DIFERENSIASI PRODUK DAN DIFERENSIASI CITRA SERTA PENGARUHNYA TERHADAP KINERJA PEMASARAN IKM KOPI DI KABUPATEN TEMANGGUNG
}

\author{
Ela Wulandari ${ }^{1}$, Indri Murniawaty ${ }^{2 *}$ \\ ${ }^{1,2}$ Jurusan Pendidikan Ekonomi, Fakultas Ekonomi, Universitas Negeri Semarang \\ Kampus Sekaran Gunungpati, Semarang 50229, Indonesia \\ *Penulis korespondensi; Email: indrimurniawaty@mail.unnes.ac.id
}

\begin{abstract}
Abstrak: Penelitian ini bertujuan untuk mengetahui pengaruh diferensiasi produk dan diferensiasi citra terhadap keunggulan bersaing dan pengaruhnya terhahadap kinerja pemasaran Industri Kecil Menengah Kopi di Kabupaten Temanggung. Populasi dalam penelitian ini sebanyak 156 responden. Teknik pengambilan sampel menggunakan teknik proporsional area random sampling, penentuan jumlah sampel menggunakan rumus Slovin, sehingga diperoleh 61 responden dengan taraf signifikansi $10 \%$. Metode pengumpulan data dengan kuesioner dan dokumentasi. Analisis data menggunakan SEM PLS (Structural Equation Modeling Partial Least Square). Hasil analisis menunjukkan hasil yang signifikan dan positif dari diferensiasi produk terhadap keunggulan bersaing, sedangkan diferensiasi citra tidak berpengaruh signifikan terhadap keunggulan bersaing dan keunggulan bersaing berpengaruh positif dan signifikan terhadap kinerja pemasaran. Simpulan yang diperoleh adalah semakin tinggi perusahaan menerapkan strategi diferensiasi produk maka akan meningkatkan keunggulan bersaing, namun semakin tinggi diferensiasi citra yang diterapkan perusahaan belum tentu meningkatkan keunggulan bersaing dan keunggulan bersaing meningkatkan kinerja pemasaran.
\end{abstract}

Kata kunci: Competitive advantage; image differentiation; marketing performance; product differentiation.

\begin{abstract}
This research aims to determine the effect of product differentiation and image differentiation in creating competitive advantage and its influence on marketing performance Small Medium and Entreprises (SMEs) of Coffee in Temanggung Regency. Population in this research are 156 SME's respondent. The sampling technique used was proportional area random sampling technique, determining the number of samples used the Slovin formula, so that 61 respodents were obtained with a significance level of 10\%. Research methods which applied in this research is questionnaires and documentation. This study used SEM PLS (Structural Equation Modeling Partial Least Square). The results of this research show significant and positive results of product differentiation on competitive advantage, while image differentiation does not have a significant effect on competitive advantage and competitive advantage has a positive and significant effect on marketing performance. The conclusions obtained are that the higher the company implements a product differentiation strategy it will increase competitive advantage, but the higher the image differentiation applied by the company does not necessarily improve competitive advantage and competitive advantage can improve marketing performance.
\end{abstract}

Keywords: Competitive advantage; image differentiation; marketing performance; product differentiation.

\section{PENDAHULUAN}

Bisnis di abad 21 akan semakin banyak menghadapi tantangan karena konsumen lebih memandang kepada produk yang lebih high-quality, lowcost dan bisnis tersebut diatas juga harus responsif terhadap perubahan yang sangat cepat (Tampi, 2015). Menurut (Frices, 2009) bahwa globalisasi ekonomi memberikan harapan baru pada besarnya peluang pangsa pasar maka hanya negara-negara, daerah-daerah dan perusahaan-perusahaan yang mempunyai daya saing yang tangguh dan mempunyai keunggulan komparatif yang tinggi yang akan menang dalam persaingan tersebut. Perusahaan harus menciptakan daya saing khusus untuk memperkuat posisi tawar-menawar dalam persaingan, serta untuk menampung tuntutan persaingan di pasar yang berasal dari para pemasok, pembeli, ancaman pendatang baru, produk pengganti dan tantangan gencar lainnya dari para pesaing (Suryana, 2006).

Salah satu strategi bersaing yang dapat digunakan adalah strategi diferensiasi yang dipelopori Michael Porter 1980. Hal ini sesuai dengan penelitian yang dipelopori oleh Ferdinand (2003) bahwa salah satu bentuk strategi persaingan yang dapat diambil dan lazim digunakan adalah strategi diferensiasi (Porter, 1980) dan karena itu perusahaan berlombalomba untuk mengembangkan berbagai "point of differentiation" (Ferdinand, 2002) yang akan diterapkan sebagai salah satu instrumen utama untuk menghasilkan kinerja pemasaran (Ferdinand, 2003:1). Satwika dan Ni Made (2018) dalam penelitiannya menyatakan bahwa untuk meningkatkan kinerja, perusahaan perlu menonjolkan keunggulan kompetitif 
dari produk yang dihasilkan, serta melakukan orienttasi dan inovasi agar bertahan dalam persaingan yang ada. Penelitian yang dilakukan oleh Chi-Chuan Wu et al (2011) tentang Customer Satisfaction Loyalty menunjukkan bahwa Brand Image/citra merek tidak memiliki pengaruh yang positif dan signifikan terhadap loyalitas konsumen. Akan tetapi penelitian yang dilakukan oleh Hakim \& Faizah (2017) menjelaskan bahwa pencapaian pemasaran diferensiasi menggunakan citra cukup efektif. Hal serupa juga dinyatakan oleh Putu \& Erna (2017) bahwa variabel diferensiasi layanan, diferensiasi personil dan diferensiasi citra masing-masing memiliki pengaruh kuat terhadap upaya membangun keunggulan bersaing. Penelitian yang dilakukan oleh Kung'u \& Machuki (2016) tentang The Effect of Competitive Strategis on Performance menyebutkan bahwa terdapat hubungan antara strategi kompetitif dan kinerja, dimana menggunakan strategi kompetitif kepemimpinan biaya, strategi diferensiasi, strategi fokus dan disiplin nilai.

Statistik Perkebunan Indonesia Komoditas Kopi 2015-2017 yang dikeluarkan Direktorat Jendral Perkebunan menunjukkan bahwa, Kabupaten Temanggung merupakan sentra kopi di Jawa Tengah dengan memiliki hasil produksi 7.536 ton kopi robusta dan 1.109 ton kopi arabika.

Kementrian Hukum dan HAM RI mengeluarkan sertifikasi Indikasi Geografis (IG) kepada Kopi Java Arabika Sindoro-Sumbing pada tahun 2014 dan Kopi Robusta Temanggung pada 6 Desember 2016, yaitu sertifikasi yang menunjukkan daerah asal dan/ atau produk karena faktor lingkungan geografis termasuk faktor alam, faktor manusia atau kombinasi dari kedua faktor tersebut memberikan reputasi, kualitas, karakteristik tertentu pada barang dan/produk yang dihasilkan sebagai ciri khas daerah untuk meningkatkan daya saing lokal Indonesia di kancah Internasional, sehingga berpotensi menjadi sumber devisa negara. Oleh karena itu, peneliti menjadikan diferensiasi produk dan diferensiasi citra sebagai variabel penelitian dan pengaruhnya terhadap keunggulan bersaing untuk meningkatkan kinerja pemasaran pada Industri Kecil Menengah Kopi di Kabupaten Temanggung.

\section{KAJIAN TEORI}

\section{Kinerja Pemasaran}

Kinerja pemasaran merupakan konsep untuk mengukur prestasi suatu produk. Setiap perusahaan berkepentingan untuk mengetahui prestasi pasar dari produk-produkya, sebagai cermin dari keberhasilan usahanya di dunia bisnis (Wahyono, 2002). Selanjutnya Supranoto (2009) menyatakan bahwa kinerja pemasaran merupakan ukuran prestasi yan diperoleh dari aktifitas proses pemasaran secara menyeluruh dari sebuah perusahaan atau organisasi. Selain itu, kinerja pemasaran juga dapat dipandang sebagai sebuah konsep yang digunakan untuk mengukur sampai mana prestasi pasar yang telah dicapai oleh suatu produk yang dihasilkan perusahaan.

\section{Diferensiasi Produk}

Diferensiasi produk adalah penciptaan suatu produk atau citra produk yang cukup berbeda dengan produk-produk yang telah beredar dengan maksud untuk menarik konsumen (Griffin, 2003). Dengan adanya diferensiasi poduk, konsumen akan lebih tertarik karena barang yang dihasilkan oleh perusahaan dianggap berbeda, terdapat banyak pilihan baik dari segi rasa, warna, bentuk maupun kemasan yang disajikan atau unik menurut konsumen sehingga konsumen tertarik untuk membeli produk yang dihasilkan oleh perusahaan yang melakukan diferensiasi produk (Tarida, 2012). Penelitian yang dilakukan oleh Tampi (2015) menunjukkan bahwa diferensiasi produk berpengaruh positif dan signifikan terhadap keunggulan bersaing. Sedangkan penelitian yang dilakukan oleh Asa (2008) membuktikan bahwa diferensiasi tidak mempengaruhi keunggulan bersaing bila produknya merupakan produk standar.

\section{Diferensiasi Citra}

Citra adalah presepsi masyarakat terhadap perusahaan atau produknya, citra dipengaruhi oleh banyak faktor yang diluar control perusahaan (Kotler, 2002). Kotler dan Killer (2007) dalam Muntaha \& Sutrisna (2018) berpendapat bahwa diferensiasi citra adalah menciptakan pembeda dalam hal keyakinan, gagasan dan kesan yang dimiliki seseorang berkaitan dengan suatu objek tertentu atau perusahaan untuk menciptakan suatu nilai yang dapat dipergunakan untuk menciptakan konsumen yang loyal. Penelitian yang dilaku

kan oleh Paryanti (2015) membuktikan bahwa diferensiasi citra berpengaruh terhadap keunggulan bersaing. Akan tetapi penelitian dari Tampi (2015) menyatakan bahawa secara parsial tidak ada pengaruh signifikan atara diferensiasi citra terhadap keunggulan bersaing.

\section{Keunggulan Bersaing}

Keunggulan bersaing (competitive advantage) merupakan sekumpulan faktor yang membedakan perusahaan kecil dari para pesaignya dan memberikan posisi unik di pasar sehingga lebih unggul dari para pesaingnya. Keunggulan bersaing juga dapat diartikan 
sebagai keunggulan yang menciptakan nilai bagi pelanggan dan sukar ditiru oleh para pesaing. Perusahaan yang memiliki keunggulan bersaing akan menjadi pemimpin dalam pasarnya serta dapat mencapai laba di atas rata-rata (Zimmerer, 2008). Keunggulan bersaing/kompetitif adalah suatu manfaat yang ada ketika suatu perusahaan mempunyai dan menghasilkan suatu produk dan atau jasa yang dilihat dari pasar targetnya lebih baik dibanding dengan kompetitor terdekat (Saiman, 2015).

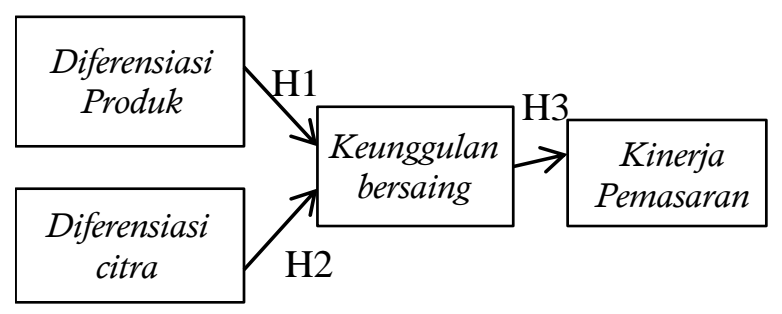

Gambar 1. Model Penelitian

\section{Hipotesis}

H1: Diferensiasi Produk berpengaruh signifikan terhadap Keunggulan Bersaing IKM Kopi di Kabupaten Temanggung.

H2: Diferensiasi Citra berpengaruh signifikan terhadap keunggulan bersaing IKM Kopi di Kabupaten Temanggung.

H3: Keunggulan bersaing berpengaruh signifikan terhadap kinerja pemasaran IKM Kopi di Kabupaten Temanggung.

\section{METODE PENELITIAN}

Penelitian ini menggunakan metode kuantitatif. Populasi dalam penelitian ini adalah pelaku industri kecil menengah (IKM) Kopi di Kabupaten Temanggung yang memiliki kriteria yaitu, 1) memproduksi kopi bubuk, 2) kopi bubuk memiliki nama/merek, 3) terdaftar di Dinas Pertanian dan Ketahan Pangan Kabupaten Temanggung Per 31 Desember 2018. Jumlah populasi IKM Kopi di Kabupaten Temanggung sebanyak 156 IKM Kopi, jumlah tersebut berdasarkan data dari Dinas Pertanian dan Ketahanan Pangan Kabupaten Temanggung. Teknik pengambilan sampel dilakukan secara proporsional area random sampling, penentuan jumlah sampel menggunakan rumus Slovin (Sugiyono, 2016). Sehingga berdasarkan hasil perhitungan diperoleh jumlah sampel yaitu 61 responden dengan taraf kesalahan 10\%.

Metode pengumpulan data dalam penelitian ini menggunakan kuesioner dan dokumentasi. Sifat kuesioner adalah kuesioner tertutup dan menggunakan skala Likert. Teknik pengolahan dan analisis data yaitu menggunakan analisis statistik deskriptif persen- tase yang terdiri dari deskriptif responden dan deskripsi variabel penelitian serta menggunakan analisis structural equation model partial least square (SEM PLS) yang terdiri dari uji inner dan outer model. Analisis data bersifat kuantitatif/statistik dengan tujuan untuk menguji hipotesis yang ditetapkan. PLS-SEM bertujuan untuk menguji hubungan prediktif antar konstruk dengan melihat apakah ada hubungan atau pengaruh antar konstruk tersebut. Konsekuensi penggunaan PLS-SEM adalah pengujian dapat dilakukan tanpa dasar teori yang kuat, mengabaikan asumsi (non-parametrik) dan parameter ketepatan prediksi dilihat dari nilai koefisien determinasi (R-Squre). Karena itu, PLS-SEM sangat tepat digunakan pada penelitian yang bertujuan untuk menggembangkan teori (Ghozali \& Latan, 2015). Desain penelitian ini adalah penelitian kausalitas.

Indikator yang digunakan dalam variabel diferensiasi produk yaitu bentuk, fitur (keistimewaan), kualitas kesesuaian dan gaya. Variabel diferensiasi citra menggunakan indikator lambang, media cetak/ audio visual, suasana/tempat, dan peristiwa. Variabel keunggulan bersaing menggunakan indikator harga/ nilai, berbeda dengan yang lain dan tidak mudah digantikan. Variabel kinerja pemasaran menggunakan indikator pertumbuhan penjualan, pertumbuhan pelanggan, pertumbuhan laba dan porsi pasar.

\section{HASIL PENELITIAN}

\section{Analisis Deskripsi Respoden}

Data penelitian diperoleh dengan membagikan kuesioner kepada pelaku IKM Kopi di Kabupaten Temanggung. Penelitian ini menunjukkan bahwa responden berjenis kelamin laki-laki lebih banyak dibanding perempuan yaitu sebanyak 54 (88.52\%) sisanya 7 (11.48\%) adalah perempuan. Hal ini dikarenakan mayoritas industri kopi di Kabupaten Temanggung berangkat dari petani kopi sebagai mata pencaharian utama yang dipimpin olek keluarga. Dilihat dari usia responden bahwa persentase usia responden paling besar dalam penelitian ini adalah usia 41-50 tahun yaitu sebanyak 23 (37.71\%), selanjutnya usia 31-40 tahun sebanyak 15 (24.59\%), usia kurang dari 30 tahun sebanyak 14 (22.95\%) dan sisanya $9(14.75 \%)$ adalah usia lebih dari 50 tahun. Hal ini dikarenakan industri kopi di Kabupaten Temanggung mayoritas berawal dari petani kopi yang menambah nilai jual kopi menjadi kopi bubuk yang berkualitas. Selain itu industri kopi berkembang 4 -5 tahun terakhir, sehingga para pelaku IKM Kopi yang masih usia muda yaitu usia dari 30-40 tahun ikut meramaikan perkembangan kopi saat ini yang semakin digemari. Persentase tingkat pendidikan res- 
ponden pada penelitian ini paling banyak adalah lulusan SMA yaitu sebanyak 27 (44.26\%). Hal ini dikarenakan industri kopi berkembang 4 tahun terakhir dan sedang digemari kalangan anak muda. Mayoritas pendidikan terakhir anak muda sekarang adalah SMA sederajat. Lamanya waktu jalannya usaha suatu perusahaan sangat berkaitan dengan kemampuan seorang wirausaha dalam menerapkan strategi usahanya. Berdasarkan hasil penelitian ini bahwa persentase paling besar adalah dibawah 5 tahun.

\section{Analisis Deskripsi Variabel Penelitian}

Hasil analisis deskriptif variabel kinerja pemasaran termasuk dalam kategori baik dengan persentase sebesar 73,65\%. Hal ini menunjukkan bahwa rata-rata responden memilih jawaban skala empat yaitu baik dengan jumlah $31(50,82 \%)$ responden. Selanjutnya variabel keunggulan bersaing termasuk dalam kategori baik dengan persentase 76,02\%. Hal ini menunjukkan bahwa rata-rata responden memilih jawaban skala empat yaitu baik dengan jumlah 42 $(68,85 \%)$ responden. Variabel diferensiasi produk termasuk dalam kategori baik dengan persentase sebesar $82,52 \%$. Hal ini menunjukkan bahwa rata-rata responden memilih skala empat yaitu baik dengan jumlah $37(60,66 \%)$ responden. Sedangkan sisanya $24(39,34 \%)$ responden memilih pada skala lima yaitu sangat baik. Dalam penelitian ini variabel diferensiasi produk memiliki nilai persentase paling banyak. Hasil analisis deskriptif variabel diferensiasi citra termasuk dalam kategori baik dengan persentase $69,66 \%$. Persentase tersebut hampir mendekati kategori kurang baik. Dalam hal ini, 42,62\% responden memiliki kriteria kurang baik. Dalam penelitian ini variabel diferensisi citra memiliki persentase paling rendah dari variabel lainnya. Artinya, diferensiasi citra belum di jalankan dengan maksimal.

\section{Uji Outer Model atau Model Pengukuran}

Uji outer model digunakan untuk menguji validitas dan reliabilitas. Kriteria yang digunakan untuk menilai outer model antara lain adalah validitas convergent dan reliabilitas

\section{Uji Validitas Convergent}

Model ini digunakan untuk menguji validitas indikator dengan melihat masing-masing konstruk. Uji validitas convergent indikator reflektif dengan program SmartPLS 3.0 dapat dilihat dari loadng factor dan average variance extracted (AVE).

\section{Loading Factor}

Loading Factor menjadi kriteria dalam menilai validitas convergent. Jika dilihat dari loading factor maka ukuran reflektif dikatakan bagus apabila nilainya lebih dari 0.70 , konstruk dengan nilai kurnag dari 0.70 harus dihapus atau didrop agar dapat menghasilkan model yang baik dari sebelumnya. Nilai loading factor dapat dilihat dari tabel outer loading pada tabel 1 .

Konstruk DP 2 dan KP2 pada tabel 5 mempunyai loading factor kurang dari 0.7. Sehingga indikator konstruk dengan nilai loading factor (original sampel) yang kurang dari 0,7 harus dihapus (drop) agar mampu menghasilkan model yang lebih baik dari model sebelumnya.

Tabel 1. Outer Loading (Mean, STDEV, T-Values, P-Values

\begin{tabular}{|c|c|c|c|c|c|}
\hline & $\begin{array}{c}\text { Original Sample } \\
(\mathbf{O})\end{array}$ & $\begin{array}{c}\text { Sample Mean } \\
\text { (M) }\end{array}$ & $\begin{array}{c}\text { Standard Deviation } \\
\text { (STDEV) }\end{array}$ & $\begin{array}{c}\text { T Statistics } \\
\text { (IO/STDEV) }\end{array}$ & P Values \\
\hline$\overline{\mathrm{DC} 1<-\mathrm{DC}}$ & 0,749 & 0,698 & 0,258 & 2,899 & 0,002 \\
\hline $\mathrm{DC} 2<-\mathrm{DC}$ & 0,826 & 0,750 & 0,276 & 2,993 & 0,001 \\
\hline $\mathrm{DC} 3<-\mathrm{DC}$ & 0,842 & 0,770 & 0,242 & 3,482 & 0,000 \\
\hline $\mathrm{DC} 4<-\mathrm{DC}$ & 0,771 & 0,695 & 0,276 & 2,799 & 0,003 \\
\hline $\mathrm{DP} 1<-\mathrm{DP}$ & 0,826 & 0,806 & 0,136 & 6,068 & 0,000 \\
\hline $\mathrm{DP} 2<-\mathrm{DP}$ & 0,670 & 0,633 & 0,183 & 3,673 & 0,000 \\
\hline DP3<-DP & 0,793 & 0,771 & 0,127 & 6,260 & 0,000 \\
\hline $\mathrm{DP} 4<-\mathrm{DP}$ & 0,795 & 0,792 & 0,112 & 7,092 & 0,000 \\
\hline $\mathrm{KB} 1<-\mathrm{KB}$ & 0,746 & 0,731 & 0,144 & 5,172 & 0,000 \\
\hline $\mathrm{KB} 2<-\mathrm{KB}$ & 0,878 & 0,871 & 0,066 & 13,293 & 0,000 \\
\hline $\mathrm{KB} 3<-\mathrm{KB}$ & 0,786 & 0,763 & 0,125 & 6,271 & 0,000 \\
\hline $\mathrm{KP} 1<-\mathrm{KP}$ & 0,850 & 0,819 & 0,164 & 5,171 & 0,000 \\
\hline $\mathrm{KP} 2<-\mathrm{KP}$ & 0,915 & 0,887 & 0,153 & 5,970 & 0,000 \\
\hline $\mathrm{KP} 3<-\mathrm{KP}$ & 0,769 & 0,729 & 0,180 & 4,277 & 0,000 \\
\hline $\mathrm{KP} 4<-\mathrm{KP}$ & 0,599 & 0,583 & 0,149 & 4,010 & 0,000 \\
\hline
\end{tabular}

Sumber: Output SmartPLS 3.0, 2019 


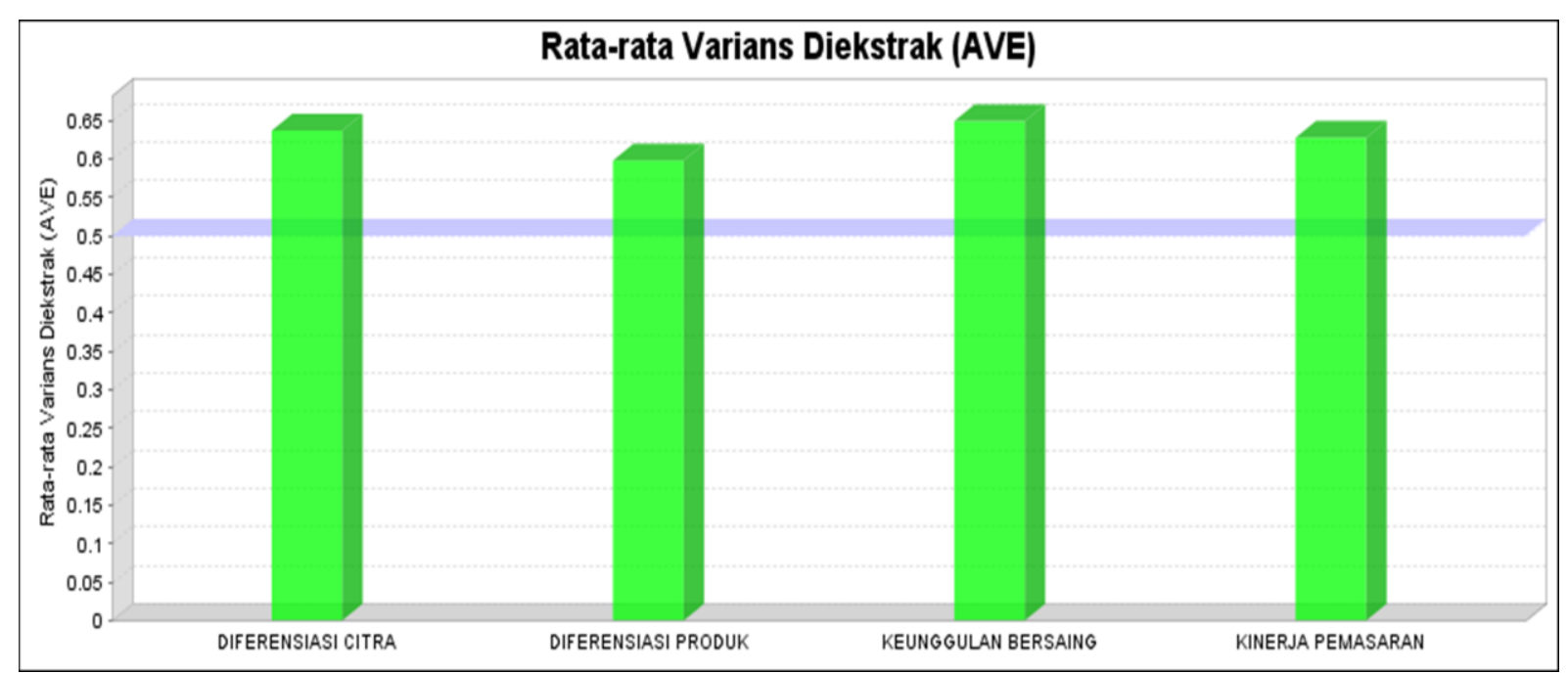

Sumber: Output SmartPLS 3.0, 2019

Gambar 2. Diagram AVE

\section{Average Variance Extracted (AVE).}

AVE merupakan salah satu parameter untuk menikai validitas convergent. Variabel laten dikatakan valid jika nilai AVE lebih dari 0.5. Nilai AVE direkomendasikan harus lebih dari 05 mempunyai arti bahwa 50\% atau lebih variance dari indikator dapat dijelaskan (Ghozali \& Latan, 2015). Nilai AVE dibawah ini sudah menunjukkan nilai lebih dari 0.5.

\section{Uji Reliabilitas}

Tujuan dari uji reliabilitas adalah untuk mengukur konsistensi jawaban responden. Uji reliabilitas dapat diukur dengan dua kriteria yaitu cronbach's alpha dan composite reliability. Sebuah konstruk memiliki reliabilitas yang baik jika cronbach's alpha dan composite reliability lebih dari 0.7 . Berikut hasil output nilai Cronbach's alpha dan composite reliability

Tabel 2. Cronbach's Alpha dan Composite Reliability

\begin{tabular}{lcc}
\hline & $\begin{array}{c}\text { Cronbach's } \\
\text { Alpha }\end{array}$ & $\begin{array}{c}\text { Composite } \\
\text { Reliability }\end{array}$ \\
\hline Diferensiasi Produk & 0,788 & 0,823 \\
Diferensiasi Citra & 0,830 & 0,891 \\
Kinerja Pemasaran & 0,798 & 0,897 \\
Keunggulan Bersaing & 0,753 & 0,831 \\
\hline
\end{tabular}

Sumber: Output SmartPLS 3.0, 2019.

\section{Uji Inner Model atau Model Struktural}

Pengujian inner model atau model struktural dilakukan untuk melihat hubungan antar konstruk, nilai signifikan, dan R-Square dari model penelitian. Berikut adalah hasil pengujian R-Square menggunakan SmartPLS 3.0 yang disajikan dalam Tabel berikut.
Tabel 3. Nilai R-Square

\begin{tabular}{lc}
\hline & R-Square \\
\hline Keunggulan Bersaing & 0,306 \\
Kinerja Pemasaran & 0,146 \\
\hline
\end{tabular}

Sumber: Output SmartPLS 3.0, 2019.

Tabel 3 menunjukkan hasil pengaruh variabel laten independent terhadap variabel laten dependen keunggulan bersaing 30,6\% sedangkan sisanya yaitu $69,4 \%$ dijelaskan oleh faktor lain yang tidak dijelaskan dalam model. Pengaruh variabel laten keunggulan bersaing hanya $14,6 \%$ sisanya dijelaskan oleh faktor lain yang tidak dijelaskan dalam model. Namun, $\mathrm{R}^{2}$ bukanlah parameter absolut dalam mengukur ketepatan model prediksi karena dasar hubungan teoritis adalah parameter yang paling utama untuk menjelaskan hubungan kausalitas tersebut (Abdillah $\&$ Hartono, 2015).

\section{Uji Hipotesis}

Metode pengujian hipotesis dalam penelitian ini menggunakan Structural Equation Model (SEM) berbasis variance dengan menggunakan SmartPLS 3.0. Berikut merupakan hasil pengujian Full Model SEM Algorithm.

Uji hipotesis dilakukan dengan melihat nilai path coefficient yang menunjukkan koefisien parameter dan nilai t-statistic. Jika t-statistik lebih tinggi dibandingkan nilai t-tabel, berarti hipotesis terdukung atau diterima. Dalam penelitian ini untuk tingkat keyakinan 95\% persen (alpha 95 persen), maka nilai t-tabel untuk hipotesis satu ekor (one-tailed) adalah > 1,64. Tabel dibawah ini meyajikan pengujian path coefficient dengan SmartPLS 3.0. 


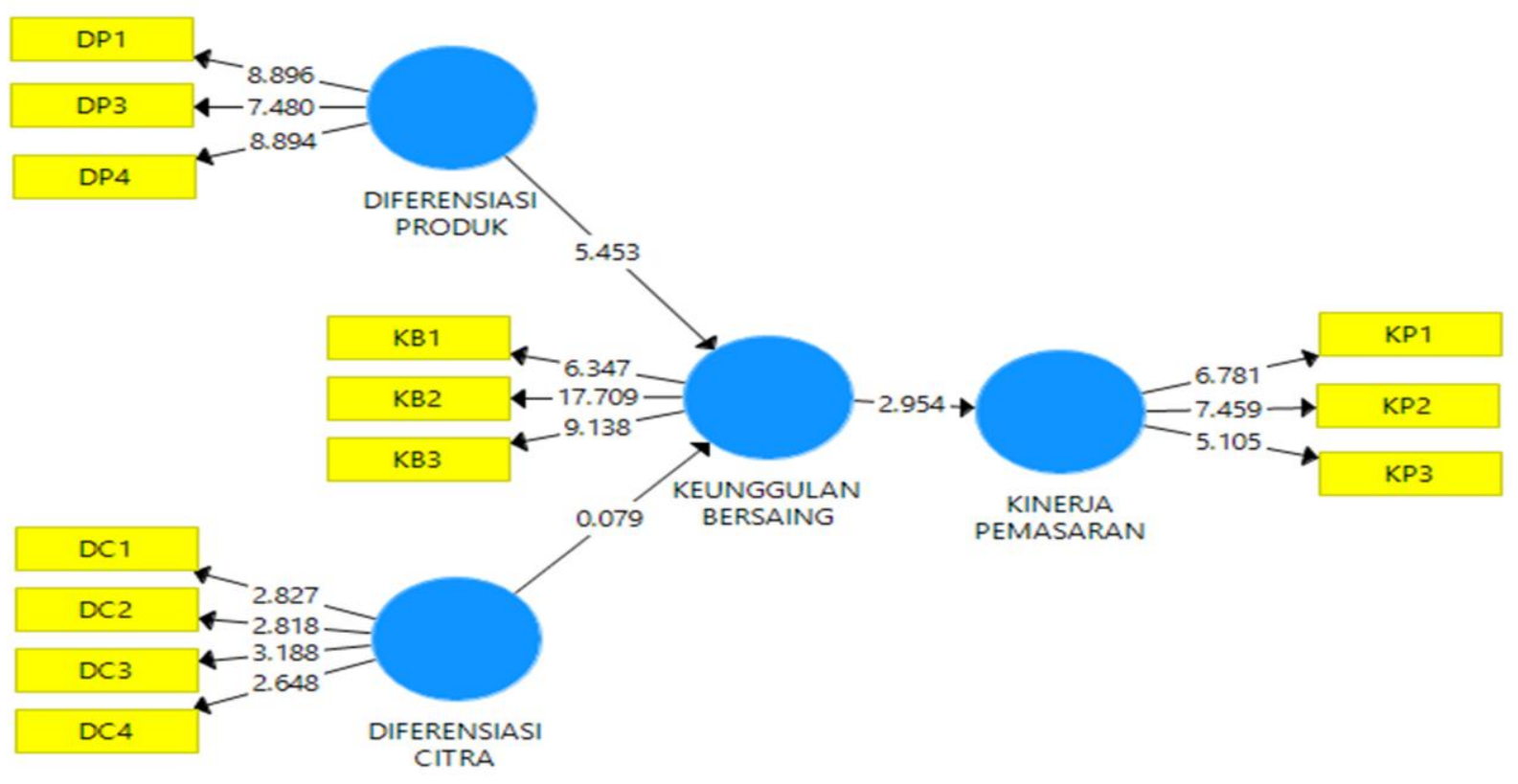

Gambar 3. Uji Full Model SEM Algorithm

Tabel 4. Path Coefficient (Mean, STDEV, T-Values, $P$ Values)

\begin{tabular}{lccccc}
\hline & $\begin{array}{c}\text { Original } \\
\text { Sample } \\
(\mathbf{O})\end{array}$ & $\begin{array}{c}\text { Sample } \\
\text { Mean } \\
(\mathbf{M})\end{array}$ & $\begin{array}{c}\text { Standard } \\
\text { Deviation } \\
\text { (STDEV) }\end{array}$ & $\begin{array}{c}\text { T Statistics } \\
(\mid \mathbf{O} / \text { STDEV }\end{array}$ & $\begin{array}{c}\mathbf{P} \\
\text { Values }\end{array}$ \\
\hline DC-KB & 0,011 & 0,055 & 0,135 & 0,079 & 0,469 \\
DP-KB & 0,547 & 0,542 & 0,100 & 5,453 & 0,000 \\
KB-KP & 0,381 & 0,393 & 0,129 & 2,954 & 0,002 \\
\hline
\end{tabular}

Sumber: Output SmartPLS 3.0, 2019

\section{Pengaruh Diferensiasi Produk terhadap Keung- gulan Bersaing}

Hasil uji resampling bootstrapping diperoleh nilai parameter koefisien untuk variabel diferensiasi produk terhadap keunggulan bersaing sebesar 0,547 dengan nilai t-statistik sebesar 5,453. Hal tersebut menunjukkan bahwa diferensiasi produk berpengaruh signifikan terhadap keunggulan bersaing dikarenakan nilai t-statistik lebih besar dari 1, 64. Sehingga dapat diambil kesimpulan bahwa H1 diterima karena diferensiasi produk memiliki hubungan positif dan signifikan terhadap keunggulan bersaing.

\section{Pengaruh Diferensiasi Citra terhadap Keunggul- an Bersaing}

Hasil uji resampling bootstrapping diperoleh nilai parameter untuk variabel citra terhadao keunggulan bersaing sebasar 0,011 dengan nilai t-statistik sebesar 0,079. Hal tersebut menunjukkan bahwa diferensiasi citra tidak berpengaruh signifikan terhadap keunggulan bersaing dikarenakan nilai t-statistik lebih dari 1,64. Sehingga dapat diambil kesimpul- an $\mathrm{H} 2$ ditolak karena tidak ada pengaruh signifikan dari diferensiasi citra terhadap keunggulan bersaing.

\section{Pengaruh Keunggulan Bersaing terhadap Kinerja Pemasaran}

Hasil uji resampling bootstrapping diperoleh nilai parameter koefisien untuk variabel keunggulan bersaing terhadap kinerja pemsaran sebesar 0,381 dengan nilai t-statistik sebesar 2,954. Hal tersebut menunjukkan bahwa keunggulan bersaing berpengaruh signifikan terhadap kinerja pemasaran dikarenakan nilai t-statistik lebih besar dari 1,64. Selain itu, pengaruh variabel keunggulan bersaing terhadap kinerja pemasaran adalah positif. Sehingga dapat diambil kesimpulan bahwa H3 diterima karena keunggulan bersaing memiliki hubungan positif dan signifikan terhadap kinerja pemasaran.

\section{PEMBAHASAN}

\section{Diferensiasi Produk Berpengaruh terhadap Ke- unggulan Bersaing}

Hipotesis satu (H1) menyatakan bahwa diferensiasi produk berpengaruh signifikan terhadap keunggulan bersaing adalah diterima. Berdasarkan hasil penelitian bahwa diferensiasi produk dapat mempengaruhi keunggulan bersaing, selain itu diferensiasi produk memiliki hubungan yang positif terhadap keunggulan bersaing. Teori keunggulan bersaing yang dipelopori Porter, menjelaskan bahwa beberapa strategi yang dapat digunakan perusahaan untuk dapat bersaing yaitu dengan mengimplementasikan strategi 
generiknya (biaya rendah, diferensiasi dan fokus). Strategi diferensiasi adalah kemampuan perusahaan untuk menghasilkan barang dan jasa yang unik dalam industrinya. Diferensiasi dapat dilakukan dalam beberapa bentuk, salah satunya dengan diferensiasi produk. Menurut Sahetapy (2013) diferensiasi produk adalah kegiatan memodifikasi produk menjadi menarik, biasanya hanya mengubah sedikit karakter produk, antara lain kemasan dan tema promosi tanpa mengubah spesifikasi fisik produk meskipun itu diperlukan.

Diferensiasi produk kopi yang dibangun melalui bentuk, kualitas kesesuaian dan gaya mampu meningkatkan keunggulan bersaing. Indikator bentuk dan gaya memiliki pengaruh yang lebih besar daripada indikator kualitas kesesuaian. Indikator bentuk yaitu meliputi menyediakan ukuran kemasan yang bervariasi, menjual kopi murni, menjual kopi dalam bentuk greanbean dan rostbean perlu ditingkatkan untuk menciptakan keunggulan bersaing. Indikator gaya perlu ditingkatkan melalui memberikan bentuk kemasan yang menarik, menggunakan biji kopi yang diperik merah dan memperhatikan pengolahan pasca panen untuk membuat kopi yang berkualitas.

Hasil penelitian ini sejalan dengan penelitian yang dilakukan oleh Tampi (2015) bahwa diferensiasi produk berpengaruh signifikan terhadap keunggulan bersaing. Hasil yang sama ditemukan dalam penelitian Lestari (2005) yang membuktikan bahwa diferensiasi produk berpengaruh positif dan signifikan terhadap keunggulan bersaing yaitu sebesar 0,427 dan berpengaruh terhadap kinerja pemasaran.

\section{Diferensiasi Citra Berpengaruh terhadap Ke- unggulan Bersaing}

Hipotesis dua (H2) menyatakan bahwa diferensiasi citra berpengaruh signifikan terhadap keunggulan bersaing adalah ditolak. Hasil ini berdasarkan hasil penelitian bahwa diferensiasi citra tidak berpengaruh terhdap keunggulan bersaing. Hal ini dapat dimaknai bahwa meningkatnya atau menurunya keunggulan bersaing dari pemasaran secara bermakna tidak disebabkan karena strategi diferensiasi citra. Apabila dilihat dari deskripsi variabel diferensiassi citra terdapat $42,62 \%$ responden memiliki kriteria kurang baik dalam menerapkan diferensiasi citra. Meskpun variabel diferensiasi citra memiliki rata-rata dalam kriteria baik, akan tetapi nilai tersebut mendekati kriteria kurang baik. Sehingga dapat dilihat bahwa pelaku IKM Kopi di Kabupaten Temanggung belum memaksimalkan diferensiasi citra. Sehingga hasil penelitian ini, diferensiasi citra tidak berpengaruh terhadap keunggulan bersaing IKM Kopi di Kabupaten Temanggung. Hasil penelitian ini sejalan dengan
Tampi (2015) bahwa diferensiasi citra tidak berpengaruh terhadap keunggulan bersaing. Selain itu Chi-Chuan Wu et al., (2011) yang penelitiannya tentang Customer Satisfaction Loyalty menunjukkan bahwa brand image/citra merek tidak memilikipengaruh yang positif dan signifikan terhadap loyalitas konsumen.

\section{Keunggulan Bersaing Berpengaruh terhadap Kinerja Pemasaran}

Hipotesisi tiga (H3) menyatakan bahwa keunggulan bersaing berpengaruh signifikan terhadap keunggulan bersaing adalah diterima. Hal ini berdasarkan hasil penelitian bahwa keunggulan bersaing dapat mempengaruhi kinerja pemasaran, selain itu keunggulan bersaing memiliki hubungan yang positif terhadap kinerja pemasaran. Pengujian variabel keunggulan bersaing terhadap kinerja pemasaran menunjukkan bahwa semakin baik keunggulan bersaing akan meningkatkan kinerja pemasaran. Perusahaan yang mampu menciptakan strategi bersaing akan menciptakan keunggulan bersaing dari para pesaingnya sehingga akan meningkatkan penjualan perusahaan. Day dan Wensley dalam (Crevens, 1996) mengemukakan bahwa keunggulan bersaing seharusnya dipandang sebagai suatu proses dinamis ketimbang sebagai hasil akhir. Sedangkan menurut Ferdinand dalam (Sismanto, 2006) menyatakan bahwa perusahaan berkepentingan untuk mengetahui prestasi pasar dari produk-produknya, dimana kinerja pemasaran merupakan konsep untuk mengukur prestasi pasar suatu produk. Keunggulan bersaing IKM Kopi dengan indikator nilai, berbeda dengan yang lain dan tidak mudah digantikan berpengaruh terhadap kinerja pemasaran IKM Kopi yaitu meningkatkan partumbuhan penjualan, pertumbuhan pelanggan dan pertumbuhan laba dimana yang paling dominan adalah pertumbuhan pelanggan.

Penelitian ini sejalan dengan penelitian yang dilakukan oleh (Dewi, 2006) yang membuktikan bahwa keunggulan bersaing berpengaruh positif dan signifikan terhadap kinerja pemasaran pada industry batik di Kota dan Kabupaten Pekalongan. Penelitian yang sama juga dibuktikan oleh Tampi (2015) bahwa keunggulan bersaing secara parsial berpengaruh signifikan terhadap kinerja pemasaran. Hasil tersebut juga mendukung pendapat bahwa strategi diferensiasi akan menjadi instrumen yang baik untuk menghasilkan kinerja pemasaran. Penelitian yang dilakukan oleh Kung'u \& Machuki (2016) tentang The Effect of Competitive Strategis of Performance menyebutkan bahwa terdapat hubungan antara strategi kompetitif dan kinerja, dimana menggunakan strategi kompetitif kepemimpinan biaya, strategi diferensiasi, strategi fokus dan disiplin nilai. 


\section{SIMPULAN}

Simpulan dari penelitian ini menunjukkan bahwa diferensiasi produk berpengaruh terhadap keunggulan bersaing industri kecil menengah Kopi di Kabupaten Temanggung sebesar 0,547. Diferensiasi citra tidak berpengaruh terhadap keunggulan bersaing dan keunggulan bersaing berpengaruh terhadap kinerja pemasaran industri kecil menengah Kopi di Kabupaten Temanggung sebesar 0,381. Hal tersebut menunjukkan bahwa pelaku industri kecil menengah Kopi di Kabupaten Temanggung sudah dapat menerapkan strategi diferensiasi produk dengan baik, akan tetapi belum maksimal dalam menerapkan strategi diferensiasi citra. Berdasarkan penelitian ini, diharapkan pelaku Industri Kopi di Kabupaten Temanggung dapat meningkatkan kualitas produk agar dapat bersaing dan bertahan di pasaran.

\section{DAFTAR PUSTAKA}

Abdillah, W., \& Hartono, J. (2015). Partial Least Square (PLS). Yogyakarta: C.V ANDI OFFSET.

Asa, M. F. (2008). Faktor-Faktor Kritis dalam Sistem Manajemen Mutu (SMM) untuk Optimasi Profitabilitas dan Daya Saing Perusahaan Jasa Konstruksi di Indonesia. Jurnal Teknik Sipil, 15(3), 99-106.

Crevens, D. W. (1996). Pemasaran Strategis. Jakarta: Erlangga.

Dewi, S. T. (2006). Analisis Pengaruh Orientasi Pasar Dan Inovasi Produk Terhadap Keunggulan Bersaing Untuk Meningkatkan Kinerja Pemasaran (Studi pada Industri Batik di Kota dan Kabupaten Pekalongan) TESIS Diajukan untuk memenuhi sebagian syarat guna memperoleh derajat sarja. UNDIP.

Ferdinand, A. (2003). Keunggulan Diferensiasif Dan Kinerja Pemasaran. Jurnal Bisnis Strategi, $12(8), 1-18$.

Frices, H. (2009). Globalisasi: Respons Terhadap Krisis Ekonomi. Jogjakarta: Midi Pustaka.

Ghozali, I., \& Latan, H. (2015). Partial Least Squares Konsep, Teknik dan Aplikasi Menggunakan Program SmartPLS 3.0. Semarang: Badan Penerbit-UNDIP.

Hakim, M. A., \& Faizah, N. (2017). Analisis Strategi Diferensiasi Citra Perusahaan Dalam Pemasaran Sebagai Upaya Untuk Menciptakan Keunggulan Bersaing ( Studi Pada Pt. Ar Tour \& Travel ). Bisnis, 5(2), 383-406.

International Coffee Organization. (2019). Full-Text. London: International Coffe Organization.

Jill, G. (2003). Customer Loyalty=Menumbuhkan dan Mempertahankan Kesetiaan Pelanggan (Diterjemah). Jakarta: Erlangga.
Kotler, P. (2002). Manajemen Pemasaran edisi Milinium 1. Jakarta: PT Prenhallindo.

Kung'u, P. W., \& Machuki, V. (2016). An Analysis Of The Effect Of Competitive Strategies On Performance: A Survey of Mfis in Kenya. Journal of Business and Strategic Management (JBSM), 1(2), 21-41.

Lestari, D. E. (2005). Analisis Strategi Diferensiasi Yang Mempengaruhi Keunggulan Bersaing dan Pengaruhnya Terhadap Kinerja Pemasaran. UNDIP.

Muchlas, Z. (2015). Strategi Inovasi Dan Daya Saing Industri Kecil Menengah (Ikm) Agro Industri Di Kota Batu. Jurnal JIBEKA, 9(2), 78-91.

Muntaha, A. S., \& Sutrisna, E. (2018). Pengaruh Strategi Diferensiasi Terhadap Loyalitas Konsumen Bisnis Jasa Pengiriman Pt. Pos Indonesia (Persero) Pekanbaru. Jom Fisip, 5(1), 1-15.

Paryanti, R. (2015). Pengaruh Strategi Diferensiasi Terhadap Keunggulan Bersaing (Studi Pada Hotel resty Menara Pekanbaru). JOM FISIP, 2(2), 2-13.

Perkebunan, D. J. (2017). Statistik Perkebunan Indonesia 2015-2017 Kopi. Jakarta: Sekretariat Direktorat Jenderal Perkebunan, Direktorat Jenderal Perkebunan dan Kementrian Pertanian.

Putu, N., \& Erna, D. (2017). Membangun Keunggulan Bersaing Pada Hotel Alila Ubud Fakultas Ekonomi dan Bisnis Universitas Udayana, Bali , Indonesia 6(11), 6120-6140.

Sahetapy, J. P. (2013). Diferensiasi Produk, Strategi Merek, Pengaruhnya Terhadap Keputusan Pembelian Meubel UD Sinar Sakti Manado. EMBA, 1(3), 411-420.

Saiman, L. (2015). Kewirausahaan Teori, Praktik, dan Kasus-Kasus. Jakarta: Salemba Empat.

Satwika, N. K. P., \& Ni Made W.K.D. (2018). Keunggulan Kompetitif Dan Kinerja Bisnis Fakultas Ekonomi dan Bisnis Universitas Udayana, Bali , Indonesia. P, 7(3), 1481-1509.

Sismanto, A. (2006). Analisis Pengaruh Orientasi Pembelajaran, Orientasi Pasar dan Inovasi Terhadap Keunggulan Bersaing Untuk Meningkatkan Kinerja Pemasaran. UNDIP.

Suendro, G. (2010). Analisis Pengaruh Inovasi Produk Melalui Kinerja Pemasaran untuk Mencapai Keunggulan Bersaing Berkelanjutan (Studi kasus pada Industri Kecil dan Menengah Batik Pekalongan). Jurnal Sains Pemasaran Indonesia, IX(2), 230-243.

Sugiyono. (2016). Metode Penelitian Pendidikan Pendekatan Kuantitatif, Kualitatif, dan R\&D. Bandung: Alfabeta.

Supranoto, M. (2009). Strategi Menciptakan Keunggulan Bersaing Produk Melalui Orientasi Pasar. UNDIP. 
Suryana. (2006). Kewirausahaan Pedoman Praktis: Kiat dan Proses Menuju Sukses. Jakarta: Salemba Empat.

Tampi, N. (2015). Analisis Strategi Diferensiasi Produk, Diferensiasi Layanan dan Diferensiasi Citra Terhadap Keunggulan Bersaing dan Kinerja Pemasaran (Studi Pada PT. Telkomsel Grapari Manado). Jurnal EMBA, ISSN: 2303$1174,3(4), 68-81$.

Tarida, Y. (2012). Ekonomi pembangunan. Jurnal Ekonomi Pembangunan, 10(2), 124-142.

Vanessa, D. C., \& Hendra, N. T. (2014). Pengaruh Orientasi Kewirausahaan, Inovasi Produk, dan Keunggulan Bersaing terhadap Kinerja Pema- saran Usaha Nasi Kuning. Jurnal EMBA, 2(3), 1214-1224.

Wahyono. (2002). Orientasi Pasar dan Inovasi: Pengaruhnya Terhadap Kinerja Pemasaran. Jurnal Sains Pemasaran Indonesia, 1(1), 23-40.

Wu, C. C., Liao, S. H., Chen, Y. J., \& Hsu, W. L. (2011). Service Quality, Brand Image And Price Fairness Impact On The Customer Satisfaction And Loyalty. IEEE International Conference On Industrial Engineering And Engineering Management, 1160-1164.

Zimmerer, T. W. dan N. M. S. (2008). Kewirausahaan dan Manajemen Usaha Kecil. Jakarta: Salemba Empat. 